\title{
A MAGYAR SZEMÉLYISÉGLEÍRÓ MELLÉKNEVEK SZOCIÁLIS KÍVÁNATOSSÁGA
}

\author{
SZIRMÁK ZSÓFIA \\ Universität Bielefeld, Fakultät für Gesundheitswissenschaften, Németország \\ E-mail:szirmak@post.uni-bielefeld.de
}

A magyar személyiségszókincs taxonómiai vizsgálatához kapcsolódóan (SZIRMÁK, DE RAAD, 1994) 620, a magyar személyiségtaxonómia alapját alkotó személyiségleiró melléknevek szociális kivánatosságát, azaz szociális elfogadottsági vagy tetszési szintjét vizsgáltam. A tanulmány a személyiségleiró melléknevek szociális kivaánatosságának középértékét, szórását, z-értékét, valamint gyakorisági eloszlását mutatja be tíz itész hétfokú skálán végzett osztályzatai alapján. A dolgozat emellett a személyiségleiró melléknevek szociális kívánatosságának kutatási irányzatait ismerteti, valamint betekintést enged az angol, német és holland nyelvü taxonómiai kutatáshoz kapcsolódó szociáliskívánatosság-vizsgálatok eredményeibe.

Kulcsszavak: $\quad$ Személyiségleíró szókincs, szociális kíuánatosság, személyiségtaxonómia, Big-Five

\section{BEVEZETÉS}

Az ötfaktoros személyiségleíró modell (Big Five Modell) népszerűsége (részletesen lásd SzIrMák, DE RAAD, 1994) nagyban hozzájárult a személyiségvonások szerepének előtérbe kerüléséhez a mai pszichológiában (JOHN, 1990). A személyiségleíró szókincs struktúrájának vizsgálatát számos indoeurópai nyelvcsoporthoz tartozó nyelven megelőzte vagy követte a személyiségleíró szavak szociális kívánatosságának feltérképezése. A magyar személyiségleíró szavak szociális kívánatosságáról máig nem állnak a kutatók rendelkezésére átfogó adatok. Ez a tanulmány ezt a hiányt igyekszik pótolni.

Történeti összefüggésben EDWARDS (1957) munkája nyitott új távlatokat a szociális tetszésigény mint személyiségjellemző kutatására a személyiségvizsgálatok területén. Ez a dimenzió fontos szerepet tölt be még OsGOOD (1962) és PEABODY (1967) munkáiban, de a Crowne és Marlowe (1960; Marlowe, Crowne, 1961; lásd Millham, JaCoBson, 1978/1983) szerzőpáros kutatásainak is központjában áll. 
EDWARDS 1957-es tanulmányában a következőképpen határozza meg a szociális kívánatosság jelentését: „Az a potenciális torzító hatás, amely a kísérleti személyek személyiség-kérdőívek állításaira adott egyirányúan befolyásolt válaszaiban nyilvánul meg.” (P. VI.; a szerző fordítása.)

Edwards a szociális kívánatosság, illetve a tetszésigény kutatásában a személyiségtesztek, különös tekintettel az MMPI releváns állításaira szorítkozott, ennélfogva az ezekből kifejlesztett szociális kívánatosság skála elkerülhetetlenül pszichopatológiás vetülettel rendelkezett. CROWNE és MARLOWE (1960) bírálatukban azt hangsúlyozzák, hogy normál populációban alkalmazva az ilyen tételekből álló kérdőív eredményei nem értelmezhetők egyértelműen, és félrevezető következtetésekhez vezethetnek.

A Marlowe-Crowne-féle Social Desirability Scale (Szociális Kívánatosság Skála) állításai a személyiség-kérdőívekben talált patológiásan nem releváns, mindamellett csekély valószínűséggel előforduló társadalmilag elfogadott, illetve gyakran előforduló, de elutasított magatartásformákra vonatkoznak (CROWNE, MARLOWE, 1960). E szerzők definíciójában a szociális tetszésigény a társas elfogadottság iránti motivációra utal, és az egyes személyeknek a társadalmilag elfogadott és jutalmazott viselkedésre irányuló igényét fejezi ki. Mindez azt a meggyőződést tükrözi, hogy a társadalom által helyénvalónak tartott és jutalmazott viselkedésminták alkalmazásával a társas elfogadottság igénye kielégíthető (CROWNE, MARLOWE, 1960; MARLOWE, CROWNE, 1961). Munkájukban kitérnek a szociális tetszési igény és a konformitás egymáshoz való kapcsolatára, s e két fogalom különbözőségét abban látják, hogy míg a tetszésigény motivációs jellegü változó, addig a konformitás a viselkedések egy osztályára alkalmazott meghatározás (MARLOWE, CROWNE, 1961).

Ezek a korai tanulmányok a személyiségtaxonómiai kutatások lexikai szókincsre koncentráló vizsgálatainak előzményei is, és melléknévszókincsük egyes esetekben a lexikai vizsgálatokban is felhasználásra került. A szociális kívánatosság, a kérdőívállítások, illetve a személyiségleírók szociális elfogadottságának vizsgálata azonban nemcsak a személyiségtaxonómiában, hanem a pszichológia más területein is fontos szerepet játszik.

Mint MERVIELDE (1977) megállapítja, a személyiségszókincs szociális kívánatosságára vonatkozó normatív adatok nemcsak a személyiségre vonatkozó szóhasználat kulturális és nyelvi eltéréseire vetnek fényt, hanem a személyiségpercepció és a véleményalkotás kutatásában is segítséget nyújtanak. A személyiségleírók szociális kívánatosság értékének vitathatatlanul fontos szerepe van a személyiségpszichológiai tesztek kifejlesztéséhez kapcsolódó kutatásokban (CROWNE, 1979; HAMPSON, GOLDBERG, JOHN, 1987; VERKASALO, Lindeman, 1994), a személyekről alkotott hétköznapi véleményformálásban (KLAPPROT, 1994), a tulajdonságlisták összeállításában, valamint a beállítódások megítélésében (BUSZ, CoHEN, Poser, Schümer, A., SChümer, R., SOnnenfeld, 1994).

Egy szó vagy állítás szociális kívánatossága tendenciózusan befolyásolja a válaszolót abban, mennyiben fogadja el vagy utasítja el azt önmaga jellemzésére. A szociális kívánatosság értéke alapján magas valószínűséggel bejósolható egy-egy állítás pozitív, illetve negatív megítélésének mértéke (EDWARDS, 1957). A további- 
akban azokat a kutatásokat ismertetem röviden, amelyek vagy a lexikai hipotézisen alapuló taxonómiai munkákhoz kapcsolódnak szervesen, vagy pedig a lexikai hipotézis értelmében vizsgálódásaikat nem összetett állításokra, hanem független személyiségleíró melléknevekre alapozták.

A személyiségleíró szavak szociális kívánatosságáról mind a mai napig leggyakrabban idézett angol nyelvü munka majd harminc éve jelent meg ANDERSON (1968) tollából. E szerző ALLPORT és ODBERT (1936) vonáslistájából a leggyakrabban használt, kizárólag személyiségtartalmú és általánosan ismert mellékneveket választotta ki. ANDERSON (1968) tanulmánya 100 ítész hétfokú skálán adott osztályzatai alapján szolgáltatott adatokat 555 személyiségreleváns melléknév szociális kívánatosságának középértékéről és szórásáról. (Ugyanebben a tanulmányban a szavakat jelentéstartalmuk világossága alapján is megítéltette Anderson; a jelentéstartalom-vizsgálatban 50 ítész vett részt, és a használt skála ötfokú volt.) A vizsgálat rámutatott a személyiségreleváns szavak eloszlásának bimodalitására, amenynyiben az első adatokat szolgáltatta a személyiségleírók negatív vagy pozitív jelentéstöltődéséről, a negatív töltésű szavak enyhe túlsúlyáról, valamint a semleges tartalmú szavak viszonylagosan ritka előfordulásáról. E személyiségleíró szavak listája számos későbbi szociáliskívánatosság-kutatás kiindulási pontjául szolgált (SchönBaCH, 1972; Mervilde, 1977; Hermans, De Houwer, 1994; Klapprot, 1994).

ANDERSON (1968) tanulmánya ösztönözte HAMPSON, GOLDBERG és JOHN (1987) munkáját, amelyben 573 angol személyiségleíró szó szociális kívánatosságát és jelentésspecifikusságának szintjét ítélték meg hétfokú skálán brit vizsgálati személyek $(\mathrm{N}=55)$. Az amerikai angol nyelvű személyiségleíró szavak túlnyomó többsége GOLDBERG (1982) lexikai hipotézis elve alapján ${ }^{1}$ összeállított listájából, kisebb része pedig szabad személyleírásokból merítve, illetve a kutatók egyéni megfontolásából került a listába, például: szleng kifejezések (,lökött”), állapotot kifejező melléknevek („unott”) vagy általános értelmű leírók (,jó”). HAMPSON és munkatársai (1987) vizsgálták a személyiségleírók megítélésének időbeli stabilitását, amennyiben eredményeiket összevetették Anderson 1968-as munkájával. A majd 20 éves intervallumban a szociális kívánatosság értékeinek igen magas stabilitását $(0,97)$ találták. A kutatók a brit vizsgálati mintán kapott eredményeiket összevetették NORMAN (1967) taxonómiai tanulmányának amerikai angol nyelvű 2800 szavas személyiségleíró listája szociáliskívánatosság-értékeivel is. NORMAN (1967) tanulmányában 100 michigeni egyetemi hallgató ítélt meg 2800 személyiségleíró szót kilencfokú skálán. Ezek a személyiségleírók olyan melléknevek voltak, amelyeket Norman kutatócsoportja az angol nyelvű értelmező szótárak címszavai alapján összeállított átfogó szógyüjtemény rostálása után (az ismeretlen vagy ritka, metaforikus, fizikai megjelenést leíró, illetve színező tartalmú melléknevek kizárásával) kapott.

Goldberg lexikai hipotézise: „Azok az egyének közötti megkülönböztetések, amelyek a mindennapos személyközi kommunikációban a legnagyobb fontossággal bírnak, beágyazódnak a nyelvbe. Minél fontosabb egy ilyen személyek közötti megkülönböztetés, annál valószínűbb, hogy az emberek felismerik, meg akarják nevezni, és szavakat alkotnak leírására" (GOLDBERG, 1981, 141-142, lásd SzIRMÁK, De RAAD, 1994, 40). 
HAMPSON és munkatársai (1987) az amerikai és brit mintában közösen szereplő 444 személyiségleíró szó két eltérő kulturális közegben kapott vizsgálatakor a szociális kívánatosság értékének igen magas korrelációját $(0,96)$ tapasztalták.

A szociális kívánatosság értékek nemzetközi összevetését tartalmazta CowEN és FRANKEL (1964) korai munkája is. E kutatás nem tartozik szervesen a személyiségközpontú taxonómiai munkák csoportjába, azonban személyiségleíró szavak gyűjteményén alapult és a szociális kívánatosság értékek kultúrák és nyelvek közötti stabilitását vizsgálta. CowEN (1961) 209 szavas vonáslistájából indultak ki, melyet COWEN egyéni elbírálás és „intuíció” alapján szerkesztett. Ezt a listát fordították le francia nyelvre. A fordítás 161 szó esetében volt lehetséges, és ezeket a szavakat osztályozta hétfokú skálán 67 Sorbonne-hallgató. A szociális kívánatosság francia és amerikai értékeit összevetve 0,95-ös korrelációs értéket kaptak a kutatók (Cowen, 1961). Mivel 118 szó esetében japán nyelven is rendelkezésre állt adat Cowen vonáslistájának szociáliskívánatosság-értékeiről (IWAWAKI, CowEN, 1964a, 1964b), a szerzők háromoldalú összehasonlítást is végeztek. Az eredmény ismételten magas korrelációs érték lett (amerikai-japán =0,82; japán-francia =0,85; amerikai-francia $=0,90$ ), a fordításból adódó nehézségek ellenére (KLETT, YAUKEY, 1959).

A német és amerikai-angol vonásmelléknevek szociális kívánatosság fokának hasonlóságát vizsgálták BUSz és munkatársai (1994): az anyanyelvi szótárakból kigyűjtött német vonásmelléknevekhez magas nyelvtudású ítészek kerestek megfelelő párt az andersoni melléknévlistából. A 301 német és amerikai-angol melléknévpár esetében az átlagértékek korrelációja 0,85-ös értéket ért el.

MERVIELDE (1977) hasonló módszertani eljárással kapott 0,93-as korrelációs értéket a flamand leírók és az andersoni melléknevek szociális kívánatosság átlagainak egybevetésekor, SCHÖNBACH (1972) 0,90-es korrelációs értéket talált a német és angol mintában Anderson listájának németre fordított megfelelői és az eredeti angol nyelvű andersoni melléknevek átlagértékei között.

Ezek a tanulmányok a személyiségleírók szociális megítélésének magas kultúrák közötti és időbeni stabilitásáról nyújtanak meggyőző adatokat, mindamellett fényt vetnek az egyes nyelvek jellegzetességeire, a vonások eltérő jelentéstartalmára, valamint értelmezésére az eltérő kultúrákban (LÖWAAS, 1958; SCHÖNBACH, 1972).

A taxonómiai kutatások felélénkülése szolgáltatott újabb adatokat a szociális kívánatossággal kapcsolatban tíz évvel ANDERSON (1968) és NORMAN (1967) munkája után. BROKKEN (1978) személyiségtaxonómiai kutatásai keretében állította össze holland egynyelvű lexikonok cikkelyei alapján 1203 szóból álló személyiségleíró melléknévlistáját, és e szavakat az osgoodi dimenziók szerint (OsGOOD, SuCI, TANNENBAUM, 1957) ítéltette meg vizsgálati személyeivel. A személyiségleírók „érték” dimenzióban kapott értékét, más szóval a személyiségleírók szociális kívánatosságát 71 vizsgálati személy ítélte meg négyfokú skálán. A vizsgálati személyek közötti megegyezés alfa-koefficiense ebben a dimenzióban igen magas $(0,99)$ volt. BROKKEN (1978) munkája volt az első nem angol nyelvű taxonómiai munka, és ő szolgáltatta az első, közvetlenül a személyiségtaxonómiai kutatáshoz kapcsolódó szociáliskívánatosság-értékeket a nem angol nyelvű személyiségirodalomban. 
Az őt több mint tíz évvel később német nyelvterületen követő OSTENDORF (1990) munkájában a személyiségleírók szociális kívánatossága vizsgálatának kiindulási alapjául ANGLEITNER, OSTENDORF és JOHN (1990) taxonómiájának 430 személyiségreleváns mellékneve, valamint további 393, a taxonómiai irodalomból gyüjtött vonásmelléknév (OSTENDORF, 1994) szolgált. A végső, 823 személyiségreleváns melléknevet tartalmazó listát hétfokú szociáliskívánatosság-skálán ítélte meg tíz, átlagban 39,2 éves ítész (hat nő és négy férfi). Az ítészek közötti egyetértés alfa-koefficiense 0,97 volt.

A továbbiakban a fenti tanulmányokra alapozva ismertetem és értelmezem a magyar személyiségleírók szociális kívánatosság értékével kapcsolatos első eredményeket.

\section{ELJÁRÁS}

A magyar személyiségtaxonómiai kutatásból (SzIRMÁK, DE RAAD, 1994) átvett 620 személyiségleíró melléknév szolgált a szociáliskívánatosság-vizsgálat alapjául. Ez a személyiségleíró melléknévgyüjtemény két forrásból ered: a Magyar értelmező kéziszótárból (JuHÁsz, SzŐKE, NAGY, KOVALSZKI, 1972), valamint a mai hétköznapi szókészletet is tartalmazó Magyar-angol kéziszótárból (MAGAY, ORSZÁGH, 1991). Az alapszógyüjtés, amelyet 9 ítész végzett el, a laikus beszélő által személyiségjellemzésre használatos szavakra korlátozódott. Az így kapott listából további öt független ítész kiválasztotta az ismert, a hétköznapi nyelvben személyiségleírásra használt személyiségvonás tartalmú mellékneveket. Ez a 620, a személyiségvonáskategóriába sorolható szó alkotja a jelen kutatás szókincsét.

\section{Itészek}

A vizsgálatban önkéntes magyar anyanyelvü ítészek vettek részt, valamennyien egyetemi hallgatók vagy értelmiségi dolgozók, összesen 11 személy, hét nő és négy férfi, átlag életkoruk 23,7 év (szórás = 2,00). A ítészek hasonló korúak és foglalkozásúak voltak, mint a magyar taxonómiai kutatás résztvevői (SZIRMÁK, DE RAAD, 1994), de nem voltak azonosak velük.

\section{Módszer}

Az eljárás kidolgozásában iránymutatóul OsTENDORF (1990, 1994) korábban ismertetett munkái szolgáltak. Az ítészek egy munkafüzetet kaptak kézhez, amelyben a magyar személyleíró készlet redukciója után fennmaradó 620, a hétköznapi nyelvben ismert és használt személyiségvonás tartalmú melléknév szerepelt. A melléknevek random sorrendben szerepeltek a listában, és az ítészek egy hétfokú skálán $(-3$ = nagyon nem kívánatos $\ldots+3$ = nagyon kívánatos) ítélték meg a szavak szociális kívánatosságát a következő útmutatás szerint: 
„A következő oldalakon olyan mellékneveket talál felsorolva, amelyeket önmagunk vagy mások leírására használunk a hétköznapi nyelvben. Ezek a szavak eltérnek egymástól abban, hogy mennyire kívánatos, illetve nem kívánt a jelentéstartalmuk. Arra szeretném kérni, ítélje meg, hogy ezek a tulajdonságkifejező szavak mennyiben kívánatosak, illetve nem kívánatosak egy személy tulajdonságaként az Ön véleménye szerint.”

Az útmutatás az ítészek személyes véleményére és nem a szavak általános társadalmi megítélésére fektette a hangsúlyt. A munkafüzetet az ítészek egy ülésben, papír-ceruza módszerrel töltötték ki.

\section{EREDMÉNYEK ÉS MEGBESZÉLÉS}

A tíz ítész közötti egyetértés alfa-koefficiense 0,96 volt, így nem volt szükség további ítészek bevonására a vizsgálatba.

1. táblázat. 620 magyar személyiségleíró melléknév szociális kívánatossága hétfokú skálán megítélve. A táblázat az egyes szavak szociális kívánatosságának középértékét, szórását valamint a Z-értéket tünteti fel a középértékek csökkenő sorrendjében

\begin{tabular}{|c|c|c|c|c|c|c|c|}
\hline \multirow{2}{*}{$\begin{array}{l}\text { Személyiségleíró } \\
\text { melléknév }\end{array}$} & \multicolumn{3}{|c|}{ A szociális kívánatosság } & \multirow{2}{*}{$\begin{array}{c}\text { Személyiségleíró } \\
\text { melléknév }\end{array}$} & \multicolumn{3}{|c|}{ A szociális kívánatosság } \\
\hline & átlaga & szórása & Z-értéke & & átlaga & szórása & Z-értéke \\
\hline korrekt & 2,9 & 0,32 & 1,75 & lényeglátó & 2,6 & 0,7 & 1,57 \\
\hline lelkiismeretes & 2,9 & 0,32 & 1,75 & sokoldalú & 2,6 & 0,7 & 1,57 \\
\hline öszinte & 2,9 & 0,32 & 1,75 & melegszívü & 2,6 & 0,52 & 1,57 \\
\hline kreatív & 2,8 & 0,63 & 1,69 & eszes & 2,6 & 0,52 & 1,57 \\
\hline szavahihető & 2,8 & 0,42 & 1,69 & nevetős & 2,6 & 0,52 & 1,57 \\
\hline szabadságszerető & 2,8 & 0,42 & 1,69 & gyengéd & 2,6 & 0,52 & 1,57 \\
\hline találékony & 2,8 & 0,42 & 1,69 & fantáziadús & 2,5 & 1,27 & 1,51 \\
\hline barátságos & 2,8 & 0,42 & 1,69 & életvidám & 2,5 & 0,97 & 1,51 \\
\hline gerinces & 2,7 & 0,67 & 1,63 & jóeszű & 2,5 & 0,85 & 1,51 \\
\hline fair & 2,7 & 0,67 & 1,63 & éleselméjü & 2,5 & 0,85 & 1,51 \\
\hline sokrétü & 2,7 & 0,48 & 1,63 & természetes & 2,5 & 0,85 & 1,51 \\
\hline tehetséges & 2,7 & 0,48 & 1,63 & igazmondó & 2,5 & 0,85 & 1,51 \\
\hline jószívű & 2,7 & 0,48 & 1,63 & megérto” & 2,5 & 0,71 & 1,51 \\
\hline hűséges & 2,7 & 0,48 & 1,63 & jóindulatú & 2,5 & 0,71 & 1,51 \\
\hline okos & 2,7 & 0,48 & 1,63 & emberismerő & 2,5 & 0,71 & 1,51 \\
\hline igazságos & 2,7 & 0,48 & 1,63 & nyíltszívü & 2,5 & 0,71 & 1,51 \\
\hline szeretetteljes & 2,6 & 0,84 & 1,57 & emberszerető & 2,5 & 0,71 & 1,51 \\
\hline barátkozó & 2,6 & 0,7 & 1,57 & vígkedélyű & 2,5 & 0,53 & 1,51 \\
\hline önálló & 2,6 & 0,7 & 1,57 & kedves & 2,5 & 0,53 & 1,51 \\
\hline sportszerű & 2,6 & 0,7 & 1,57 & bölcs & 2,5 & 0,53 & 1,51 \\
\hline odaadó & 2,6 & 0,7 & 1,57 & céltudatos & 2,5 & 0,53 & 1,51 \\
\hline toleráns & 2,6 & 0,7 & 1,57 & humoros & 2,5 & 0,53 & 1,51 \\
\hline humánus & 2,6 & 0,7 & 1,57 & leleményes & 2,5 & 0,53 & 1,51 \\
\hline
\end{tabular}




\begin{tabular}{|c|c|c|c|c|c|c|c|}
\hline \multirow{2}{*}{$\begin{array}{c}\text { Személyiségleíró } \\
\text { melléknév }\end{array}$} & \multicolumn{3}{|c|}{ A szociális kívánatosság } & \multirow{2}{*}{$\begin{array}{c}\text { Személyiségleíró } \\
\text { melléknév }\end{array}$} & \multicolumn{3}{|c|}{ A szociális kívánatosság } \\
\hline & \begin{tabular}{|l|} 
átlaga \\
\end{tabular} & szórása & Z-értéke & & átlaga & szórása & Z-értéke \\
\hline emberséges & 2,4 & 1,26 & 1,45 & kollegiális & 2,0 & 0,94 & 1,2 \\
\hline nagylelkü & 2,4 & 0,84 & 1,45 & talentumos & 2,0 & 0,94 & 1,2 \\
\hline áld ozatkész & 2,4 & 0,7 & 1,45 & gyakorlatias & 2,0 & 0,82 & 1,2 \\
\hline jóakaró & 2,4 & 0,7 & 1,45 & tapasztalt & 2,0 & 0,82 & 1,2 \\
\hline bajtársias & 2,4 & 0,7 & 1,45 & igyekvő & 2,0 & 0,82 & 1,2 \\
\hline bátor & 2,4 & 0,7 & 1,45 & elmés & 2,0 & 0,82 & 1,2 \\
\hline szellemes & 2,4 & 0,7 & 1,45 & tréfás & 2,0 & 0,82 & 1,2 \\
\hline éleslátású & 2,4 & 0,7 & 1,45 & szókimondó & 2,0 & 0,67 & 1,2 \\
\hline szorgalmas & 2,4 & 0,7 & 1,45 & diszkrét & 2,0 & 0,67 & 1,2 \\
\hline nyílt & 2,4 & 0,7 & 1,45 & következetes & 1,9 & 1,85 & 1,14 \\
\hline tisztességes & 2,4 & 0,7 & 1,45 & kulturált & 1,9 & 1,85 & 1,14 \\
\hline önkritikus & 2,4 & 0,7 & 1,45 & dinamikus & 1,9 & 1,45 & 1,14 \\
\hline határozott & 2,4 & 0,52 & 1,45 & felelősségteljes & 1,9 & 1,45 & 1,14 \\
\hline kitartó & 2,4 & 0,52 & 1,45 & rátermett & 1,9 & 1,29 & 1,14 \\
\hline vendégszerető & 2,3 & 1,57 & 1,39 & optimista & 1,9 & 1,29 & 1,14 \\
\hline nemes & 2,3 & 0,95 & 1,39 & megfontolt & 1,9 & 1,2 & 1,14 \\
\hline temperamentumos & 2,3 & 0,82 & 1,39 & jómodorú & 1,9 & 1,2 & 1,14 \\
\hline etikus & 2,3 & 0,82 & 1,39 & stílusos & 1,9 & 1,2 & 1,14 \\
\hline türelmes & 2,3 & 0,67 & 1,39 & karakán & 1,9 & 0,99 & 1,14 \\
\hline jóérzésű & 2,3 & 0,67 & 1,39 & konzekvens & 1,9 & 0,99 & 1,14 \\
\hline szolidáris & 2,3 & 0,48 & 1,39 & lángeszu” & 1,9 & 0,99 & 1,14 \\
\hline gyöngéd & 2,2 & 1,87 & 1,33 & racionális & 1,9 & 0,88 & 1,14 \\
\hline segítőkész & 2,2 & 1,55 & 1,33 & bizakodó & 1,9 & 0,88 & 1,14 \\
\hline ötletgazdag & 2,2 & 1,32 & 1,33 & körültekintő & 1,9 & 0,88 & 1,14 \\
\hline öntevékeny & 2,2 & 0,79 & 1,33 & bőkezű & 1,9 & 0,88 & 1,14 \\
\hline eleven & 2,2 & 0,79 & 1,33 & kiforrott & 1,9 & 0,74 & 1,14 \\
\hline udvarias & 2,2 & 0,79 & 1,33 & tetterős & 1,9 & 0,74 & 1,14 \\
\hline érzelmes & 2,2 & 0,79 & 1,33 & energikus & 1,9 & 0,74 & 1,14 \\
\hline tanulékony & 2,2 & 0,63 & 1,33 & huncut & 1,9 & 0,57 & 1,14 \\
\hline jóságos & 2,1 & 1,91 & 1,27 & tudatos & 1,9 & 0,57 & 1,14 \\
\hline figyelmes & 2,1 & 1,85 & 1,27 & igényes & 1,9 & 0,57 & 1,14 \\
\hline kiegyensúlyozott & 2,1 & 1,85 & 1,27 & megvesztegethetetlen & 1,9 & 0,32 & 1,14 \\
\hline fogékony & 2,1 & 1,85 & 1,27 & becsülettudó & 1,8 & 1,81 & 1,08 \\
\hline életteli & 2,1 & 1,6 & 1,27 & akaraterős & 1,8 & 1,75 & 1,08 \\
\hline érzéki & 2,1 & 1,29 & 1,27 & közvetlen & 1,8 & 1,55 & 1,08 \\
\hline szavatartó & 2,1 & 1,2 & 1,27 & jótékony & 1,8 & 1,48 & 1,08 \\
\hline alkalmazkodó & 2,1 & 0,88 & 1,27 & áldozatos & 1,8 & 1,32 & 1,08 \\
\hline játékos & 2,1 & 0,74 & 1,27 & intellektuális & 1,8 & 1,32 & 1,08 \\
\hline nyugodt & 2,1 & 0,74 & 1,27 & öntudatos & 1,8 & 1,23 & 1,08 \\
\hline ragaszkodó & 2,1 & 0,74 & 1,27 & szívós & 1,8 & 1,14 & 1,08 \\
\hline tapintatos & 2,1 & 0,74 & 1,27 & diplomatikus & 1,8 & 1,03 & 1,08 \\
\hline békülékeny & 2,1 & 0,57 & 1,27 & magabiztos & 1,8 & 0,92 & 1,08 \\
\hline jólelkű & 2,0 & 1,56 & 1,2 & ismerkedős & 1,8 & 0,79 & 1,08 \\
\hline intelligens & 2,0 & 1,56 & 1,2 & szívélyes & 1,8 & 0,79 & 1,08 \\
\hline nyitott & 2,0 & 1,56 & 1,2 & megnyerő & 1,8 & 0,79 & 1,08 \\
\hline erkölcsös & 2,0 & 1,15 & 1,2 & mesterkéletlen & 1,8 & 0,79 & 1,08 \\
\hline stabil & 2,0 & 1,05 & 1,2 & agyafúrt & 1,8 & 0,63 & 1,08 \\
\hline
\end{tabular}




\begin{tabular}{|c|c|c|c|c|c|c|c|}
\hline \multirow{2}{*}{$\begin{array}{c}\text { Személyiségleíró } \\
\text { melléknév }\end{array}$} & \multicolumn{3}{|c|}{ A szociális kívánatosság } & \multirow{2}{*}{$\begin{array}{c}\text { Személyiségleíró } \\
\text { melléknév }\end{array}$} & \multicolumn{3}{|c|}{ A szociális kívánatosság } \\
\hline & átlaga & szórása & Z-értéke & & átlaga & szórása & Z-értéke \\
\hline tűrőképes & 1,8 & 0,63 & 1,08 & higgadt & 1,5 & 0,71 & 0,9 \\
\hline irgalmas & 1,8 & 0,42 & 1,08 & mértéktartó & 1,5 & 0,71 & 0,9 \\
\hline szenvedélyes & 1,7 & 1,49 & 1,02 & erényes & 1,4 & 1,84 & 0,84 \\
\hline nagyvonalú & 1,7 & 1,25 & 1,02 & féltő & 1,4 & 1,35 & 0,84 \\
\hline romantikus & 1,7 & 1,25 & 1,02 & bohó & 1,4 & 1,17 & 0,84 \\
\hline fegyelmezett & 1,7 & 1,16 & 1,02 & rendszerető & 1,4 & 1,17 & 0,84 \\
\hline gondos & 1,7 & 1,16 & 1,02 & csalafinta & 1,4 & 1,07 & 0,84 \\
\hline érzékies & 1,7 & 1,16 & 1,02 & szemfüles & 1,4 & 0,97 & 0,84 \\
\hline ínyenc & 1,7 & 1,06 & 1,02 & álmodozó & 1,4 & 0,52 & 0,84 \\
\hline lényegretörő & 1,7 & 0,95 & 1,02 & ambiciózus & 1,3 & 1,7 & 0,78 \\
\hline bohókás & 1,7 & 0,95 & 1,02 & angyali & 1,3 & 1,25 & 0,78 \\
\hline alapos & 1,7 & 0,95 & 1,02 & meggyőző & 1,3 & 1,25 & 0,78 \\
\hline kifinomult & 1,7 & 0,82 & 1,02 & csintalan & 1,3 & 1,06 & 0,78 \\
\hline tisztelettudó & 1,7 & 0,82 & 1,02 & forróvérü & 1,3 & 1,06 & 0,78 \\
\hline szerény & 1,7 & 0,67 & 1,02 & jólnevelt & 1,3 & 1,06 & 0,78 \\
\hline elszánt & 1,7 & 0,67 & 1,02 & komoly & 1,3 & 0,48 & 0,78 \\
\hline mértékletes & 1,7 & 0,67 & 1,02 & elővigyázatos & 1,3 & 0,48 & 0,78 \\
\hline béketűrő & 1,7 & 0,48 & 1,02 & talányos & 1,2 & 1,62 & 0,72 \\
\hline objektív & 1,6 & 1,78 & 0,96 & furfangos & 1,2 & 1,62 & 0,72 \\
\hline önfeláldozó & 1,6 & 1,58 & 0,96 & érzékeny & 1,2 & 1,4 & 0,72 \\
\hline meggond olt & 1,6 & 1,51 & 0,96 & csavaros eszü & 1,2 & 1,32 & 0,72 \\
\hline muzikális & 1,6 & 1,43 & 0,96 & precíz & 1,2 & 1,32 & 0,72 \\
\hline kompromisszumképes & 1,6 & 1,35 & 0,96 & rendíthetetlen & 1,2 & 1,14 & 0,72 \\
\hline kötélidegzetű & 1,6 & 1,26 & 0,96 & könyörületes & 1,2 & 1,03 & 0,72 \\
\hline önérzetes & 1,6 & 1,17 & 0,96 & ironikus & 1,2 & 0,92 & 0,72 \\
\hline szorgos & 1,6 & 1,07 & 0,96 & szolid & 1,2 & 0,79 & 0,72 \\
\hline kíváncsi & 1,6 & 0,97 & 0,96 & megingathatatlan & 1,1 & 1,37 & 0,66 \\
\hline jóhiszemű & 1,6 & 0,97 & 0,96 & célratörő & 1,1 & 1,29 & 0,66 \\
\hline gézengúz & 1,6 & 0,84 & 0,96 & feladatorientált & 1,1 & 1,2 & 0,66 \\
\hline szelíd & 1,6 & 0,84 & 0,96 & kíméletes & 1,1 & 1,2 & 0,66 \\
\hline elnéző & 1,6 & 0,7 & 0,96 & büszke & 1,1 & 1,1 & 0,66 \\
\hline választékos & 1,6 & 0,7 & 0,96 & fortélyos & 1,1 & 0,99 & 0,66 \\
\hline törekvő & 1,6 & 0,7 & 0,96 & óvatos & 1,1 & 0,57 & 0,66 \\
\hline békés & 1,6 & 0,7 & 0,96 & erélyes & 1,0 & 1,25 & 0,6 \\
\hline mulatós & 1,5 & 1,84 & 0,9 & cseverésző & 1,0 & 1,15 & 0,6 \\
\hline titoktartó & 1,5 & 1,78 & 0,9 & tiszteletteljes & 1,0 & 1,05 & 0,6 \\
\hline módszeres & 1,5 & 1,72 & 0,9 & rettenthetetlen & 0,9 & 0,2 & 0,54 \\
\hline merész & 1,5 & 1,43 & 0,9 & lágyszívű & 0,9 & 0,1 & 0,54 \\
\hline élelmes & 1,5 & 1,27 & 0,9 & becsvágyó & 0,8 & 0,87 & 0,47 \\
\hline tárgyilagos & 1,5 & 0,18 & 0,9 & eltántoríthatatlan & 0,8 & 0,4 & 0,47 \\
\hline szolgálatkész & 1,5 & 1,18 & 0,9 & heves & 0,8 & 0,4 & 0,47 \\
\hline állhatatos & 1,5 & 1,18 & 0,9 & hagyománytisztelő & 0,8 & 0,4 & 0,47 \\
\hline serény & 1,5 & 1,08 & 0,9 & vajszívű & 0,8 & 0,4 & 0,47 \\
\hline kötelességtudó & 1,5 & 0,97 & 0,9 & sziklaszilárd & 0,8 & 0,32 & 0,47 \\
\hline ösztönös & 1,5 & 0,85 & 0,9 & örökmozgó & 0,8 & 0,23 & 0,47 \\
\hline hóbortos & 1,5 & 0,85 & 0,9 & szemérmes & 0,8 & 0,14 & 0,47 \\
\hline bolondos & 1,5 & 0,85 & 0,9 & \begin{tabular}{|l|} 
szuggesztív \\
\end{tabular} & 0,8 & 0,14 & 0,47 \\
\hline
\end{tabular}




\begin{tabular}{|c|c|c|c|c|c|c|c|}
\hline \multirow{2}{*}{$\begin{array}{c}\text { Személyiségleíró } \\
\text { melléknév }\end{array}$} & \multicolumn{3}{|c|}{ A szociális kívánatosság } & \multirow{2}{*}{$\begin{array}{c}\text { Személyiségleíró } \\
\text { melléknév }\end{array}$} & \multicolumn{3}{|c|}{ A szociális kívánatosság } \\
\hline & átlaga & szórása & Z-értéke & & átlaga & szórása 7 & Z-értéke \\
\hline régimódi & 0,8 & 0,92 & 0,47 & kimért & 0,0 & 0,33 & $-0,01$ \\
\hline vigyori & 0,7 & 0,64 & 0,41 & nagyravágyó & 0,0 & 0,15 & $-0,01$ \\
\hline előzékeny & 0,7 & 0,57 & 0,41 & sérülékeny & 0,0 & 0,15 & $-0,01$ \\
\hline kalandor & 0,7 & 0,57 & 0,41 & forrófejű & 0,0 & 0,15 & $-0,01$ \\
\hline buzgó & 0,7 & 0,57 & 0,41 & kielégíthetetlen & $-0,1$ & 1,9 & $-0,07$ \\
\hline zsivány & 0,7 & 0,49 & 0,41 & évezethajhászó & $-0,1$ & 1,7 & $-0,07$ \\
\hline agilis & 0,7 & 0,34 & 0,41 & gondatlan & $-0,1$ & 1,5 & $-0,07$ \\
\hline habókos & 0,7 & 0,25 & 0,41 & simulékony & $-0,1$ & 1,5 & $-0,07$ \\
\hline szófogadó & 0,7 & 0,16 & 0,41 & nagyigényü & $-0,1$ & 1,2 & $-0,07$ \\
\hline ábrándos & 0,6 & 0,51 & 0,35 & cinikus & $-0,1$ & 1,2 & $-0,07$ \\
\hline engedelmes & 0,6 & 0,51 & 0,35 & megrögzött & $-0,1$ & 1,2 & $-0,07$ \\
\hline megszállott & 0,6 & 0,35 & 0,35 & maximalista & $-0,2$ & 1,8 & $-0,13$ \\
\hline uras & 0,6 & 0,26 & 0,35 & szigorú & $-0,2$ & 1,4 & $-0,13$ \\
\hline poétikus & 0,6 & 0,26 & 0,35 & gyermeteg & $-0,2$ & 1,3 & $-0,13$ \\
\hline rejtélyes & 0,5 & 0,43 & 0,29 & csapongó & $-0,2$ & 1,3 & $-0,13$ \\
\hline pedáns & 0,5 & 0,35 & 0,29 & hóhányó & $-0,2$ & 1,1 & $-0,13$ \\
\hline csendes & 0,5 & 0,18 & 0,29 & izgulós & $-0,2$ & 1,1 & $-0,13$ \\
\hline hétalvó & 0,4 & 0,65 & 0,23 & szende & $-0,2$ & 0,92 & $-0,13$ \\
\hline jámbor & 0,4 & 0,26 & 0,23 & kótyagos & $-0,2$ & 0,92 & $-0,13$ \\
\hline szubjektív & 0,4 & 0,26 & 0,23 & sebezheto” & $-0,2$ & 0,92 & $-0,13$ \\
\hline rafinált & 0,4 & 0,26 & 0,23 & duhaj & $-0,3$ & 1,4 & $-0,19$ \\
\hline engedékeny & 0,4 & 0,07 & 0,23 & szerénytelen & $-0,3$ & 1,4 & $-0,19$ \\
\hline aprólékos & 0,4 & 0,97 & 0,23 & finomkodó & $-0,3$ & 1,2 & $-0,19$ \\
\hline naív & 0,4 & 0,84 & 0,23 & locsi-fecsi & $-0,0$ & 1,2 & $-0,19$ \\
\hline esztelen & 0,3 & 0,42 & 0,17 & ingatag & $-0,3$ & 1,1 & $-0,19$ \\
\hline kényelmes & 0,3 & 0,25 & 0,17 & feltörekvő & $-0,3$ & 1,1 & $-0,19$ \\
\hline zabolátlan & 0,3 & 0,06 & 0,17 & hallgatag & $-0,3$ & 1,0 & $-0,19$ \\
\hline lobbanékony & 0,2 & 0,4 & 0,11 & változhatatlan & $-0,4$ & 1,7 & $-0,26$ \\
\hline kategorikus & 0,2 & 0,32 & 0,11 & önfejű & $-0,4$ & 1,7 & $-0,26$ \\
\hline hevülékeny & 0,2 & 0,14 & 0,11 & körmönfont & $-0,4$ & 1,5 & $-0,26$ \\
\hline dörzsölt & 0,2 & 0,03 & 0,11 & infantilis & $-0,4$ & 1,5 & $-0,26$ \\
\hline ravasz & 0,2 & 0,03 & 0,11 & tartózkodó & $-0,4$ & 1,4 & $-0,26$ \\
\hline szabad szájú & 0,1 & 0,73 & 0,05 & babonás & $-0,4$ & 1,3 & $-0,26$ \\
\hline önmegtartóztató & 0,1 & 0,66 & 0,05 & spórolós & $-0,4$ & 1,3 & $-0,26$ \\
\hline vásott & 0,1 & 0,6 & 0,05 & okoskodó & $-0,4$ & 1,2 & $-0,26$ \\
\hline mindentudó & 0,1 & 0,52 & 0,05 & keménykezű & $-0,4$ & 1,2 & $-0,26$ \\
\hline féktelen & 0,1 & 0,52 & 0,05 & gátlásos & $-0,4$ & 1,2 & $-0,26$ \\
\hline modoros & 0,1 & 0,45 & 0,05 & engedetlen & $-0,4$ & 1,0 & $-0,26$ \\
\hline bogaras & 0,1 & 0,45 & 0,05 & hirtelen & $-0,4$ & 1,0 & $-0,26$ \\
\hline komolytalan & 0,1 & 0,29 & 0,05 & szótlan & $-0,4$ & 0,84 & $-0,26$ \\
\hline félszeg & 0,1 & 0,29 & 0,05 & zabolázhatatlan & $-0,5$ & 1,7 & $-0,32$ \\
\hline bőbeszéd ü & 0,1 & 0,2 & 0,05 & érzelgős & $-0,5$ & 1,7 & $-0,32$ \\
\hline sebezhetetlen & 0,1 & 0,2 & 0,05 & szüzi & $-0,5$ & 1,0 & $-0,32$ \\
\hline halk & 0,1 & 0,1 & 0,05 & hebehurgya & $-0,5$ & 1,0 & $-0,32$ \\
\hline vakmerő & 0,0 & 0,83 & $-0,01$ & könnyelmü & $-0,5$ & 0,97 & $-0,32$ \\
\hline alázatos & 0,0 & 0,63 & $-0,01$ & szűkszavú & $-0,5$ & 0,97 & $-0,32$ \\
\hline rámenős & 0,0 & 0,41 & $-0,01$ & kéjsóvár & $-0,6$ & 2,1 & $-0,38$ \\
\hline
\end{tabular}




\begin{tabular}{|c|c|c|c|c|c|c|c|}
\hline \multirow{2}{*}{$\begin{array}{c}\text { Személyiségleíró } \\
\text { melléknév }\end{array}$} & \multicolumn{3}{|c|}{ A szociális kívánatosság } & \multirow{2}{*}{$\begin{array}{c}\text { Személyiségleíró } \\
\text { melléknév }\end{array}$} & \multicolumn{3}{|c|}{ A szociális kívánatosság } \\
\hline & átlaga & szórása & Z-értéke & & átlaga & szórása & Z-értéke \\
\hline félrehúzódó & $-0,6$ & 1,4 & $-0,38$ & komótos & $-0,8$ & 0,42 & $-0,5$ \\
\hline pityergős & $-0,6$ & 1,2 & $-0,38$ & eszelős & $-0,9$ & 1,7 & $-0,56$ \\
\hline élvhajhászó & $-0,6$ & 1,2 & $-0,38$ & hőbörgős & $-0,9$ & 1,6 & $-0,56$ \\
\hline kevély & $-0,6$ & 1,2 & $-0,38$ & földhözragadt & $-0,9$ & 1,4 & $-0,56$ \\
\hline rendszertelen & $-0,6$ & 1,2 & $-0,38$ & fondorlatos & $-0,9$ & 1,3 & $-0,56$ \\
\hline szégyenlős & $-0,6$ & 1,1 & $-0,38$ & kiszámíthatatlan & $-0,9$ & 1,2 & $-0,56$ \\
\hline aluszékony & $-0,6$ & 1,1 & $-0,38$ & kőkemény & $-0,9$ & 1,1 & $-0,56$ \\
\hline nyughatatlan & $-0,6$ & 1,1 & $-0,38$ & türelmetlen & $-0,9$ & 1,1 & $-0,56$ \\
\hline kétbalkezes & $-0,6$ & 1,0 & $-0,38$ & sóvár & $-0,9$ & 1,1 & $-0,56$ \\
\hline szeszélyes & $-0,6$ & 0,97 & $-0,38$ & önámító & $-0,9$ & 0,88 & $-0,56$ \\
\hline megismerhetetlen & $-0,6$ & 0,97 & $-0,38$ & otthonülő & $-0,9$ & 0,88 & $-0,56$ \\
\hline maradi & $-0,6$ & 0,97 & $-0,38$ & távolságtartó & $-0,9$ & 0,74 & $-0,56$ \\
\hline zárkózott & $-0,6$ & 0,84 & $-0,38$ & bizalmatlan & $-0,9$ & 0,74 & $-0,56$ \\
\hline háborgó & $-0,6$ & 0,84 & $-0,38$ & nyers & $-0,9$ & 0,74 & $-0,56$ \\
\hline izgulékony & $-0,6$ & 0,84 & $-0,38$ & igénytelen & $-1,0$ & 1,7 & $-0,62$ \\
\hline ijedős & $-0,6$ & 0,84 & $-0,38$ & szűkmarkú & $-1,0$ & 1,7 & $-0,62$ \\
\hline félénk & $-0,6$ & 0,84 & $-0,38$ & megtört & $-1,0$ & 1,6 & $-0,62$ \\
\hline félős & $-0,6$ & 0,84 & $-0,38$ & tudálékos & $-1,0$ & 1,2 & $-0,62$ \\
\hline visszahúzódó & $-0,6$ & 0,84 & $-0,38$ & vakbuzgó & $-1,0$ & 1,2 & $-0,62$ \\
\hline lusta & $-0,6$ & 0,84 & $-0,38$ & élvsóvár & $-1,0$ & 1,1 & $-0,62$ \\
\hline anyagias & $-0,7$ & 1,8 & $-0,44$ & link & $-1,0$ & 1,1 & $-0,62$ \\
\hline akaratos & $-0,7$ & 1,2 & $-0,44$ & bágyatag & $-1,0$ & 0,94 & $-0,62$ \\
\hline gyermekded & $-0,7$ & 1,2 & $-0,44$ & szkeptikus & $-1,0$ & 0,94 & $-0,62$ \\
\hline körülményeskedő & $-0,7$ & 1,2 & $-0,44$ & szorongó & $-1,0$ & 0,82 & $-0,62$ \\
\hline izgága & $-0,7$ & 1,1 & $-0,44$ & szószátyár & $-1,0$ & 0,82 & $-0,62$ \\
\hline szemérmetlen & $-0,7$ & 1,1 & $-0,44$ & kishitű & $-1,0$ & 0,82 & $-0,62$ \\
\hline kicsapongó & $-0,7$ & 1,1 & $-0,44$ & zúgolódó & $-1,0$ & 0,82 & $-0,62$ \\
\hline nagyotmondó & $-0,7$ & 1,0 & $-0,44$ & makrancos & $-1,0$ & 0,67 & $-0,62$ \\
\hline mohó & $-0,7$ & 0,95 & $-0,44$ & elővigyázatlan & $-1,0$ & 0,67 & $-0,62$ \\
\hline elkanászosodott & $-0,7$ & 0,95 & $-0,44$ & feledékeny & $-1,0$ & 0,67 & $-0,62$ \\
\hline megközelíthetetlen & $-0,7$ & 0,82 & $-0,44$ & oktalan & $-1,0$ & 0,5 & $-0,62$ \\
\hline semmittevő & $-0,8$ & 1,8 & $-0,5$ & túlbuzgó & $-1,0$ & 0,0 & $-0,62$ \\
\hline fontoskodó & $-0,8$ & 1,6 & $-0,5$ & fukar & $-1,1$ & 2,3 & $-0,68$ \\
\hline borúlátó & $-0,8$ & 1,5 & $-0,5$ & ájuldozós & $-1,1$ & 1,6 & $-0,68$ \\
\hline ésszerűtlen & $-0,8$ & 1,5 & $-0,5$ & makacs & $-1,1$ & 1,2 & $-0,68$ \\
\hline hasznavehetetlen & $-0,8$ & 1,5 & $-0,5$ & önemésztő & $-1,1$ & 1,1 & $-0,68$ \\
\hline divatbolond & $-0,8$ & 1,4 & $-0,5$ & hűvös & $-1,1$ & 1,1 & $-0,68$ \\
\hline robbanékony & $-0,8$ & 1,4 & $-0,5$ & csapodár & $-1,1$ & 0,99 & $-0,68$ \\
\hline hiszékeny & $-0,8$ & 1,2 & $-0,5$ & határozatlan & $-1,1$ & 0,88 & $-0,68$ \\
\hline fegyelmezetlen & $-0,8$ & 1,0 & $-0,5$ & keményfejü & $-1,1$ & 0,88 & $-0,68$ \\
\hline kapkodó & $-0,8$ & 1,0 & $-0,5$ & szájtáti & $-1,1$ & 0,74 & $-0,68$ \\
\hline túlérzékeny & $-0,8$ & 1,0 & $-0,5$ & felületes & $-1,1$ & 0,32 & $-0,68$ \\
\hline rátarti & $-0,8$ & 1,0 & $-0,5$ & inkonzekvens & $-1,1$ & 0,32 & $-0,68$ \\
\hline öncélú & $-0,8$ & 0,92 & $-0,5$ & rideg & $-1,2$ & 1,8 & $-0,74$ \\
\hline bátortalan & $-0,8$ & 0,79 & $-0,5$ & orcátlan & $-1,2$ & 1,3 & $-0,74$ \\
\hline szófukar & $-0,8$ & 0,79 & $-0,5$ & csúfolkodós & $-1,2$ & 1,3 & $-0,74$ \\
\hline mániás & $-0,8$ & 0,63 & $-0,5$ & gyanakvó & $-1,2$ & 1,0 & $-0,74$ \\
\hline
\end{tabular}




\begin{tabular}{|c|c|c|c|c|c|c|c|}
\hline \multirow{2}{*}{$\begin{array}{c}\text { Személyiségleíró } \\
\text { melléknév }\end{array}$} & \multicolumn{3}{|c|}{ A szociális kívánatosság } & \multirow{2}{*}{$\begin{array}{c}\text { Személyiségleíró } \\
\text { melléknév }\end{array}$} & \multicolumn{3}{|c|}{ A szociális kívánatosság } \\
\hline & átlaga & szórása & Z-értéke & & átlaga & szórása & Z-értéke \\
\hline akadékos & $-1,2$ & 1,0 & $-0,74$ & önállótlan & $-1,4$ & 0,52 & $-0,86$ \\
\hline logikátlan & $-1,2$ & 1,0 & $-0,74$ & műveletlen & $-1,4$ & 0,52 & $-0,86$ \\
\hline duzzogós & $-1,2$ & 0,92 & $-0,74$ & akadékoskodó & $-1,4$ & 0,52 & $-0,86$ \\
\hline konok & $-1,2$ & 0,92 & $-0,74$ & aprólékoskodó & $-1,4$ & 0,52 & $-0,86$ \\
\hline előítéletes & $-1,2$ & 0,79 & $-0,74$ & fellengző & $-1,4$ & 0,52 & $-0,86$ \\
\hline butácska & $-1,2$ & 0,79 & $-0,74$ & verekedős & $-1,5$ & 1,8 & $-0,92$ \\
\hline megfáradt & $-1,2$ & 0,79 & $-0,74$ & pökhendi & $-1,5$ & 1,7 & $-0,92$ \\
\hline nehézkes & $-1,2$ & 0,63 & $-0,74$ & rosszmájú & $-1,5$ & 1,7 & $-0,92$ \\
\hline meggond olatlan & $-1,2$ & 0,42 & $-0,74$ & gőgös & $-1,5$ & 1,4 & $-0,92$ \\
\hline ingerlékeny & $-1,2$ & 0,42 & $-0,74$ & önmarcangoló & $-1,5$ & 1,2 & $-0,92$ \\
\hline pletykás & $-1,2$ & 0,42 & $-0,74$ & kritikátlan & $-1,5$ & 1,2 & $-0,92$ \\
\hline zsémbes & $-1,3$ & 1,6 & $-0,8$ & pesszimista & $-1,5$ & 1,0 & $-0,92$ \\
\hline káromkodós & $-1,3$ & 1,4 & $-0,8$ & rigolyás & $-1,5$ & 1,0 & $-0,92$ \\
\hline elkényeztetett & $-1,3$ & 1,4 & $-0,8$ & stílustalan & $-1,5$ & 0,85 & $-0,92$ \\
\hline felvágós & $-1,3$ & 1,3 & $-0,8$ & sóhajtozós & $-1,5$ & 0,71 & $-0,92$ \\
\hline elfásult & $-1,3$ & 1,3 & $-0,8$ & együgyű & $-1,5$ & 0,71 & $-0,92$ \\
\hline személyeskedő & $-1,3$ & 1,1 & $-0,8$ & hanyag & $-1,5$ & 0,71 & $-0,92$ \\
\hline törtető & $-1,3$ & 1,0 & $-0,8$ & fellengzős & $-1,5$ & 0,71 & $-0,92$ \\
\hline nyavalygós & $-1,3$ & 1,0 & $-0,8$ & neveletlen & $-1,5$ & 0,71 & $-0,92$ \\
\hline kérkedő & $-1,3$ & 0,95 & $-0,8$ & fantáziátlan & $-1,5$ & 0,71 & $-0,92$ \\
\hline önelégült & $-1,3$ & 0,95 & $-0,8$ & követelődző & $-1,5$ & 0,71 & $-0,92$ \\
\hline ötletszegény & $-1,3$ & 0,95 & $-0,8$ & tompaeszű & $-1,5$ & 0,53 & $-0,92$ \\
\hline gúnyos & $-1,3$ & 0,67 & $-0,8$ & unalmas & $-1,5$ & 0,53 & $-0,92$ \\
\hline kicsinyhitű & $-1,3$ & 0,67 & $-0,8$ & csökönyös & $-1,5$ & 0,53 & $-0,92$ \\
\hline sértődős & $-1,3$ & 0,48 & $-0,8$ & erélytelen & $-1,5$ & 0,53 & $-0,92$ \\
\hline léha & $-1,3$ & 0,48 & $-0,8$ & tetszelgő & $-1,5$ & 0,53 & $-0,92$ \\
\hline kiegyensúlyozatlan & $-1,3$ & 0,48 & $-0,8$ & alantas & $-1,6$ & 1,7 & $-0,99$ \\
\hline dölyfös & $-1,3$ & 0,48 & $-0,8$ & megátalkodott & $-1,6$ & 1,5 & $-0,99$ \\
\hline akaratgyenge & $-1,4$ & 1,7 & $-0,86$ & hisztis & $-1,6$ & 1,4 & $-0,99$ \\
\hline uralomvágyó & $-1,4$ & 1,5 & $-0,86$ & pénzsóvár & $-1,6$ & 1,1 & $-0,99$ \\
\hline önsanyargató & $-1,4$ & 1,5 & $-0,86$ & inkorrekt & $-1,6$ & 1,1 & $-0,99$ \\
\hline fensőbbséges & $-1,4$ & 1,5 & $-0,86$ & kicsinyes & $-1,6$ & 0,84 & $-0,99$ \\
\hline színlelő & $-1,4$ & 1,5 & $-0,86$ & szőrszálhasogató & $-1,6$ & 0,84 & $-0,99$ \\
\hline telhetetlen & $-1,4$ & 1,4 & $-0,86$ & kukacoskodó & $-1,6$ & 0,84 & $-0,99$ \\
\hline szőrösszívű & $-1,4$ & 1,4 & $-0,86$ & sértődékeny & $-1,6$ & 0,7 & $-0,99$ \\
\hline mesterkélt & $-1,4$ & 1,4 & $-0,86$ & felszínes & $-1,6$ & 0,7 & $-0,99$ \\
\hline nyájas & $-1,4$ & 1,2 & $-0,86$ & tutyi-mutyi & $-1,6$ & 0,7 & $-0,99$ \\
\hline gátlástalan & $-1,4$ & 1,2 & $-0,86$ & alkalmazkodásképtelen & $-1,6$ & 0,7 & $-0,99$ \\
\hline trehány & $-1,4$ & 1,1 & $-0,86$ & egoista & $-1,6$ & 0,7 & $-0,99$ \\
\hline zsörtölődő & $-1,4$ & 1,0 & $-0,86$ & udvariatlan & $-1,6$ & 0,7 & $-0,99$ \\
\hline gyengeelméjű & $-1,4$ & 1,0 & $-0,86$ & puhány & $-1,6$ & 0,52 & $-0,99$ \\
\hline körülményes & $-1,4$ & 0,97 & $-0,86$ & modortalan & $-1,7$ & 1,7 & $-1,05$ \\
\hline szürke & $-1,4$ & 0,84 & $-0,86$ & keményszívű & $-1,7$ & 1,4 & $-1,05$ \\
\hline önáltató & $-1,4$ & 0,84 & $-0,86$ & haragtartó & $-1,7$ & 1,2 & $-1,05$ \\
\hline nemtörődöm & $-1,4$ & 0,7 & $-0,86$ & alamuszi & $-1,7$ & 1,1 & $-1,05$ \\
\hline mulya & $-1,4$ & 0,7 & $-0,86$ & kötekedő & $-1,7$ & 1,0 & $-1,05$ \\
\hline hiú & $-1,4$ & 0,7 & $-0,86$ & panaszkodó & $-1,7$ & 0,95 & $-1,05$ \\
\hline
\end{tabular}




\begin{tabular}{|c|c|c|c|c|c|c|c|}
\hline \multirow{2}{*}{$\begin{array}{c}\text { Személyiségleíró } \\
\text { melléknév }\end{array}$} & \multicolumn{3}{|c|}{ A szociális kívánatosság } & \multirow{2}{*}{$\begin{array}{c}\text { Személyiségleíró } \\
\text { melléknév }\end{array}$} & \multicolumn{3}{|c|}{ A szociális kívánatosság } \\
\hline & átlaga & szórása & Z-értéke & & átlaga & szórása & Z-értéke \\
\hline álszemérmes & $-1,7$ & 0,95 & $-1,05$ & idegbajos & $-2,1$ & 1,2 & $-1,29$ \\
\hline finnyás & $-1,7$ & 0,82 & $-1,05$ & eldurvult & $-2,1$ & 0,88 & $-1,29$ \\
\hline álszerény & $-1,7$ & 0,82 & $-1,05$ & lelketlen & $-2,1$ & 0,74 & $-1,29$ \\
\hline kényes & $-1,7$ & 0,82 & $-1,05$ & fösvény & $-2,1$ & 0,74 & $-1,29$ \\
\hline hivalkodó & $-1,7$ & 0,67 & $-1,05$ & hazudós & $-2,1$ & 0,74 & $-1,29$ \\
\hline bugyuta & $-1,7$ & 0,67 & $-1,05$ & áskálódó & $-2,1$ & 0,57 & $-1,29$ \\
\hline felelőtlen & $-1,7$ & 0,67 & $-1,05$ & megvetésre méltó & $-2,2$ & 1,0 & $-1,35$ \\
\hline rest & $-1,7$ & 0,67 & $-1,05$ & összeférhetetlen & $-2,2$ & 1,0 & $-1,35$ \\
\hline következetlen & $-1,7$ & 0,67 & $-1,05$ & haszonleső & $-2,2$ & 1,0 & $-1,35$ \\
\hline önhitt & $-1,7$ & 0,67 & $-1,05$ & igazságtalan & $-2,2$ & 0,92 & $-1,35$ \\
\hline önkényes & $-1,7$ & 0,48 & $-1,05$ & kapzsi & $-2,2$ & 0,92 & $-1,35$ \\
\hline meghunyászkodó & $-1,8$ & 1,3 & $-1,11$ & hatalmaskodó & $-2,2$ & 0,92 & $-1,35$ \\
\hline fullánkos & $-1,8$ & 1,2 & $-1,11$ & hűtlen & $-2,2$ & 0,79 & $-1,35$ \\
\hline mézesmázos & $-1,8$ & 1,2 & $-1,11$ & álszent & $-2,2$ & 0,79 & $-1,35$ \\
\hline szenvtelen & $-1,8$ & 1,1 & $-1,11$ & arrogáns & $-2,2$ & 0,79 & $-1,35$ \\
\hline zsugori & $-1,8$ & 1,0 & $-1,11$ & hisztériás & $-2,2$ & 0,79 & $-1,35$ \\
\hline erkölcstelen & $-1,8$ & 1,0 & $-1,11$ & rosszindulatú & $-2,2$ & 0,79 & $-1,35$ \\
\hline megvesztegethető & $-1,8$ & 0,92 & $-1,11$ & gyủlölködő & $-2,2$ & 0,79 & $-1,35$ \\
\hline mogorva & $-1,8$ & 0,79 & $-1,11$ & szószegő & $-2,2$ & 0,63 & $-1,35$ \\
\hline fafejü & $-1,8$ & 0,79 & $-1,11$ & nagyképü & $-2,2$ & 0,42 & $-1,35$ \\
\hline beképzelt & $-1,8$ & 0,79 & $-1,11$ & képmutató & $-2,3$ & 0,82 & $-1,41$ \\
\hline őszintétlen & $-1,8$ & 0,79 & $-1,11$ & álnok & $-2,3$ & 0,82 & $-1,41$ \\
\hline árulkodós & $-1,8$ & 0,79 & $-1,11$ & önző & $-2,3$ & 0,82 & $-1,41$ \\
\hline fölényes & $-1,8$ & 0,79 & $-1,11$ & behízelgő & $-2,3$ & 0,82 & $-1,41$ \\
\hline barátságtalan & $-1,8$ & 0,63 & $-1,11$ & tyúkeszű & $-2,3$ & 0,67 & $-1,41$ \\
\hline merev & $-1,8$ & 0,63 & $-1,11$ & lelkiismeretlen & $-2,3$ & 0,67 & $-1,41$ \\
\hline emberkerülő & $-1,8$ & 0,63 & $-1,11$ & hitvány & $-2,3$ & 0,67 & $-1,41$ \\
\hline szemforgató & $-1,9$ & 0,99 & $-1,17$ & becstelen & $-2,3$ & 0,67 & $-1,41$ \\
\hline tébolyult & $-1,9$ & 0,88 & $-1,17$ & sunyi & $-2,3$ & 0,67 & $-1,41$ \\
\hline pitiáner & $-1,9$ & 0,88 & $-1,17$ & idegbeteg & $-2,3$ & 0,48 & $-1,41$ \\
\hline faragatlan & $-1,9$ & 0,88 & $-1,17$ & embertelen & $-2,4$ & 1,2 & $-1,47$ \\
\hline veszekedős & $-1,9$ & 0,88 & $-1,17$ & bosszúvágyó & $-2,4$ & 0,97 & $-1,47$ \\
\hline közönséges & $-1,9$ & 0,74 & $-1,17$ & erőszakos & $-2,4$ & 0,84 & $-1,47$ \\
\hline öntelt & $-1,9$ & 0,74 & $-1,17$ & \begin{tabular}{|l|} 
kegyetlen \\
\end{tabular} & $-2,4$ & 0,84 & $-1,47$ \\
\hline prüd & $-1,9$ & 0,74 & $-1,17$ & acsarkodó & $-2,4$ & 0,7 & $-1,47$ \\
\hline gyáva & $-1,9$ & 0,74 & $-1,17$ & durva & $-2,4$ & 0,7 & $-1,47$ \\
\hline smucig & $-1,9$ & 0,74 & $-1,17$ & rosszlelkű & $-2,4$ & 0,7 & $-1,47$ \\
\hline irigy & $-1,9$ & 0,57 & $-1,17$ & érzéstelen & $-2,4$ & 0,7 & $-1,47$ \\
\hline alattomos & $-2,0$ & 1,9 & $-1,23$ & érzéketlen & $-2,4$ & 0,52 & $-1,47$ \\
\hline kérlelhetetlen & $-2,0$ & 1,4 & $-1,23$ & hitszegő & $-2,5$ & 0,85 & $-1,53$ \\
\hline kíméletlen & $-2,0$ & 1,1 & $-1,23$ & zsarnok & $-2,5$ & 0,85 & $-1,53$ \\
\hline pofátlan & $-2,0$ & 0,94 & $-1,23$ & agresszív & $-2,5$ & 0,71 & $-1,53$ \\
\hline kőszívű & $-2,0$ & 0,94 & $-1,23$ & hatalomittas & $-2,5$ & 0,71 & $-1,53$ \\
\hline enyveskezü & $-2,0$ & 0,94 & $-1,23$ & lenéző & $-2,5$ & 0,53 & $-1,53$ \\
\hline rosszhiszemü & $-2,0$ & 0,94 & $-1,23$ & jellemtelen & $-2,6$ & 0,7 & $-1,59$ \\
\hline részeges & $-2,0$ & 0,82 & $-1,23$ & embergyűlölő & $-2,6$ & 0,52 & $-1,59$ \\
\hline hazug & $-2,1$ & 1,6 & $-1,29$ & gerinctelen & $-2,7$ & 0,67 & $-1,65$ \\
\hline
\end{tabular}




\begin{tabular}{|c|c|c|c|c|c|c|c|}
\hline \multirow{2}{*}{$\begin{array}{c}\text { Személyiségleíró } \\
\text { melléknév }\end{array}$} & \multicolumn{3}{|c|}{ A szociális kívánatosság } & \multirow{2}{*}{$\begin{array}{c}\text { Személyiségleíró } \\
\text { melléknév }\end{array}$} & \multicolumn{3}{|c|}{ A szociális kívánatosság } \\
\hline & átlaga & szórása & Z-értéke & & átlaga & szórása & Z-értéke \\
\hline alakoskodó & $-2,7$ & 0,48 & $-1,65$ & vérszomjas & $-2,8$ & 0,42 & $-1,72$ \\
\hline brutális & $-2,7$ & 0,48 & $-1,65$ & aljas & $-2,8$ & 0,42 & $-1,72$ \\
\hline gonosz & $-2,7$ & 0,48 & $-1,65$ & gonosztevő & $-2,89$ & $\mathbf{0 , 3 3}$ & $-1,77$ \\
\hline könyörtelen & $-2,7$ & 0,48 & $-1,65$ & vérengző & $-2,9$ & $\mathbf{0 , 3 2}$ & $-1,78$ \\
\hline vérszopó & $-2,7$ & 0,48 & $-1,65$ & szadista & $-3,0$ & $\mathbf{0 , 0}$ & $-1,84$ \\
\hline
\end{tabular}

Az 1. táblázat rövidített formában ${ }^{2}$ tartalmazza a 620 személyiségleíró melléknév szociális kívánatosság átlagértékét, szórását és z-értékét. A táblázatban a személyiségleírók a szociális kívánatosság csökkenő mértékében, a legkívánatosabbtól a legkevésbé kívánatos szó irányában szerepelnek. Az angol, német és holland személyiségleírókkal való összevetést megkönnyítendő, a tíz legkívánatosabb, illetve a tíz legkevésbé kívánatos melléknév vastagon nyomtatott.

A listában egyetlen szó sem éri el a maximális szociális kívánatosság értéket, a három legkívánatosabb szó (korrekt, lelkiismeretes, őszinte) 2,9 pontos átlaggal szerepel. A tíz legkívánatosabb személyiségleíró leginkább őszinteséget, kreativitást, nyitottságot fejez ki, de közvetlenül e szavak után szerepelnek a jó értelmi képességre vonatkozó melléknevek, mint például a sokrétű, tehetséges, okos (lásd a 2. táblázatot).

A 2. táblázatban feltüntetett tíz legkívánatosabb angol, német és holland nyelvủ személyiségleíró melléknevet vizsgálva megfigyelhető, hogy az őszinteséget és megbízhatóságot kifejező melléknevek mindhárom nyelv esetében az első tíz szó között szerepelnek (honest, zuverläßig, oprecht).

Ezek a taxonómiai vizsgálatok szókincse alapján nyert eredmények egybevágnak az ANDERSON-tanulmány (1968) alapján kezdett vizsgálatok eredményeivel. Amint azt SCHÖNBACH (1972) megállapítja: a becsületességet, őszinteséget kifejező melléknevek mind a német, mind pedig az angol nyelvben igen magasra értékeltek, míg ellentétpárjaik, a becstelenséget, hazugságot kifejező melléknevek erősen elítéltek, ami arra enged következtetni, hogy a másoktól elvárt őszinteségre, becsületességre való igény erős és általános szükséglet, amely kultúrától függetlenül érvényre jut. Ennek a megállapításnak az érvényességét támasztja alá, hogy nemcsak az eltérő nyelveken végzett vizsgálatok, hanem az eltérő módszerrel, eltérő alapszókészlettel, több év távlatában más-más vizsgálati csoportok esetében is megfigyelhető ez a tendencia. Mindamellett SCHÖNBACH (1972) aláhúzza, hogy a nagyfokú interkulturális hasonlóság mellett jelentős eltérések is találhatók a személyiségleírók átlagértékei között.

A legkevésbé kívánatos magyar személyiségleíró mellékneveket nézve (1. táblázat) egyetlen szó kapja meg mind a tíz ítésznél a legkedvezőtlenebb ítéletet (szadista: -3,0). A további erősen negatív töltésủ személyiségleírók jelentéstartalma brutalitást, jellemtelenséget fejez ki. A legkívánatosabb korrekt $(2,9)$, lelkiismeretes $(2,9)$, őszinte $(2,9)$ szavak ellentétpárjaként megtalálhatók az aljas $(-2,8)$, gerinctelen $(-2,7)$ és jellemtelen szavak $(-2,6)$ a lista legelítéltebb szavai között. Bár a jó

2 A táblázat teljes anyaga kutatási célra a szerző e-mail címén szerezhető meg. 


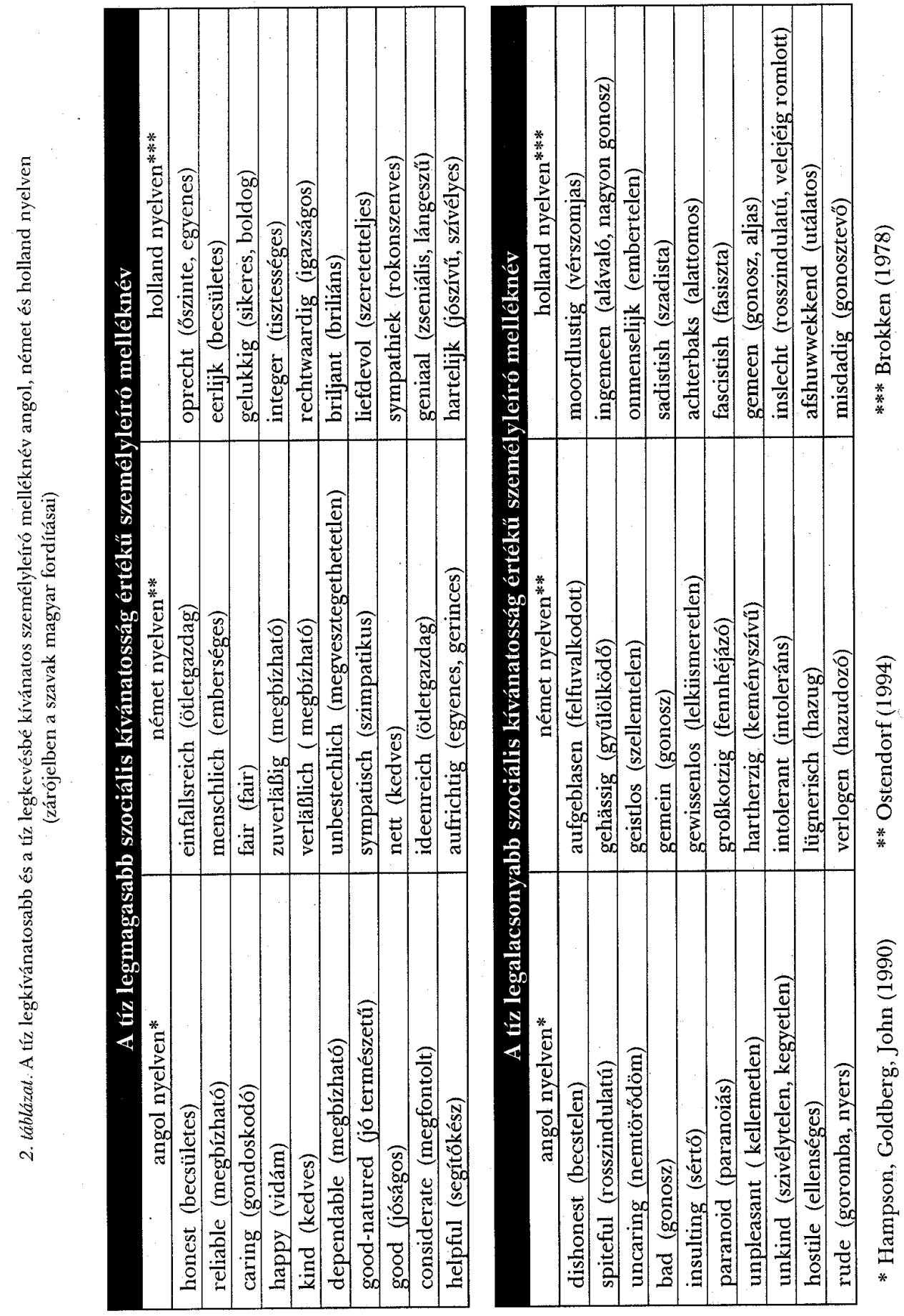


értelmi képességre vonatkozó személyiségleírók a tizenöt legkedvezőbben megítélt szó között szerepelnek, az értelmi képességek hiányára vonatkozó szavak nem olyan mértékben elutasítottak. Az első ilyen tartalmú személyiségleírót (tyúkeszű - 2,3 ) „megelőzik” az erős agresszivitást, érzéketlenséget, nemtelenséget kifejező szavak, és ezzel „csak” harmincharmadik lett a legkevésbé kívánatos szavak sorrendjében.

A leginkább elutasított angol, német és holland nyelvű személyiségvonásokat a legelutasítottabb magyar személyiségleírókkal összevetve megfigyelhető, hogy a tíz legnegatívabb jelentésű szó között több azonos jelentésű személyiségleíró is található az eltérő nyelveken. Mind a négy nyelven itt szerepel a „gonosz” (bad, gemein, gemeen) szó és ez mindegyik nyelven könyörtelenséget, rosszindulatot fejez ki. A legnagyobb a hasonlóság a holland és a magyar nyelvü leírók esetében. Ennek nem kizártan az lehet az oka, hogy e két nyelven a személyiségleírók szókészletének összeállítását nem befolyásolták egyéni kutatói döntések, azaz minden személyiségleíróként megítélt szó jelentéstartalmától függetlenül belekerült az alapszókészletbe. Ennek az eljárásnak a következtében ebben a vonáslistában az extrém jelentéstartalmú (vérszomjas, szadista) melléknevek is megtalálhatók.

A semleges megítélésű személyiségleíró szavak az 1. táblázatban a nulla átlagérték köré csoportosultan helyezkednek el. Jelentéstartalmuk leginkább a robbanékonyság-visszafogottság dimenzió mentén értelmezhető, nagyrészük dinamikusságot (vakmerő, forrófejü), illetve ennek ellentétét, visszafogottságot (kimért, alázatos) fejez ki.

A semleges megítélésű személyiségleírók viszonylag alacsony számára a magyar nyelvben a személyiségleírók szociáliskívánatosság-értékeinek gyakorisági eloszlása mutat rá. Az 1. ábrán jól megfigyelhető a személyiségleírók eloszlásának aszimmetriája, amennyiben a negatív jelentéstartalmú szavak enyhe túlsúlya mutatkozik. A magyar eredmények is azt mutatják, amit először ANDERSON (1968) angol, majd KLAPPROT (1972) német, valamint MERVIELDE (1977) holland nyelvű kutatásaik alapján megállapítanak, hogy a személyiségleíró nyelvet a semleges tartalmú leírók viszonylagos alacsony számú előfordulása jellemzi, és a nyelvet alkotó szavak többsége negatív jelentéstartalmat fejez ki. A személyiségleírók szociális kívánatosságának eloszlásában megfigyelhető aszimmetria lehetséges okait mindeddig egyetlen kutató sem vizsgálta közelebbről, a szerzők e jelenség puszta leírására szorítkoznak (ANDERSON, 1968; MERVIELDE, 1977).

A taxonómiai vizsgálatok jó alapot nyújtanak a különböző nyelvek személyiségszókincsének összehasonlítására (DE RAAD, PERUGINI, SZIRMÁK, 1997) és e kutatások keretében a személyiségleíró szavak szociális kívánatosság értékének további átfogó vizsgálatára is mód nyílik.

A tanulmány célja az első normatív adatok bemutatása a magyar személyiségleíró melléknevek szociális kívánatosságáról, és ezeknek az adatoknak az összehasonlítása az amerikai-angol, német és holland taxonómiai kutatáson alapuló szociáliskívánatosság-vizsgálatok eredményeivel.

MecklenbräUkeR, HaGer és MÖLler (1994) megállapításával összhangban szükségesnek tartom és szorgalmazom magam is az idevonatkozó vizsgálatok időszakonkénti megismétlését, hogy a társadalmi értékrend változások, valamint a sze- 
mélyes értékrend változásának hatását a személyiségleírók szociális megítélésében nyomon lehessen követni, és a személyiség- és szociálpszichológiai kutatásban a jövőben naprakészen lehessen alkalmazni.

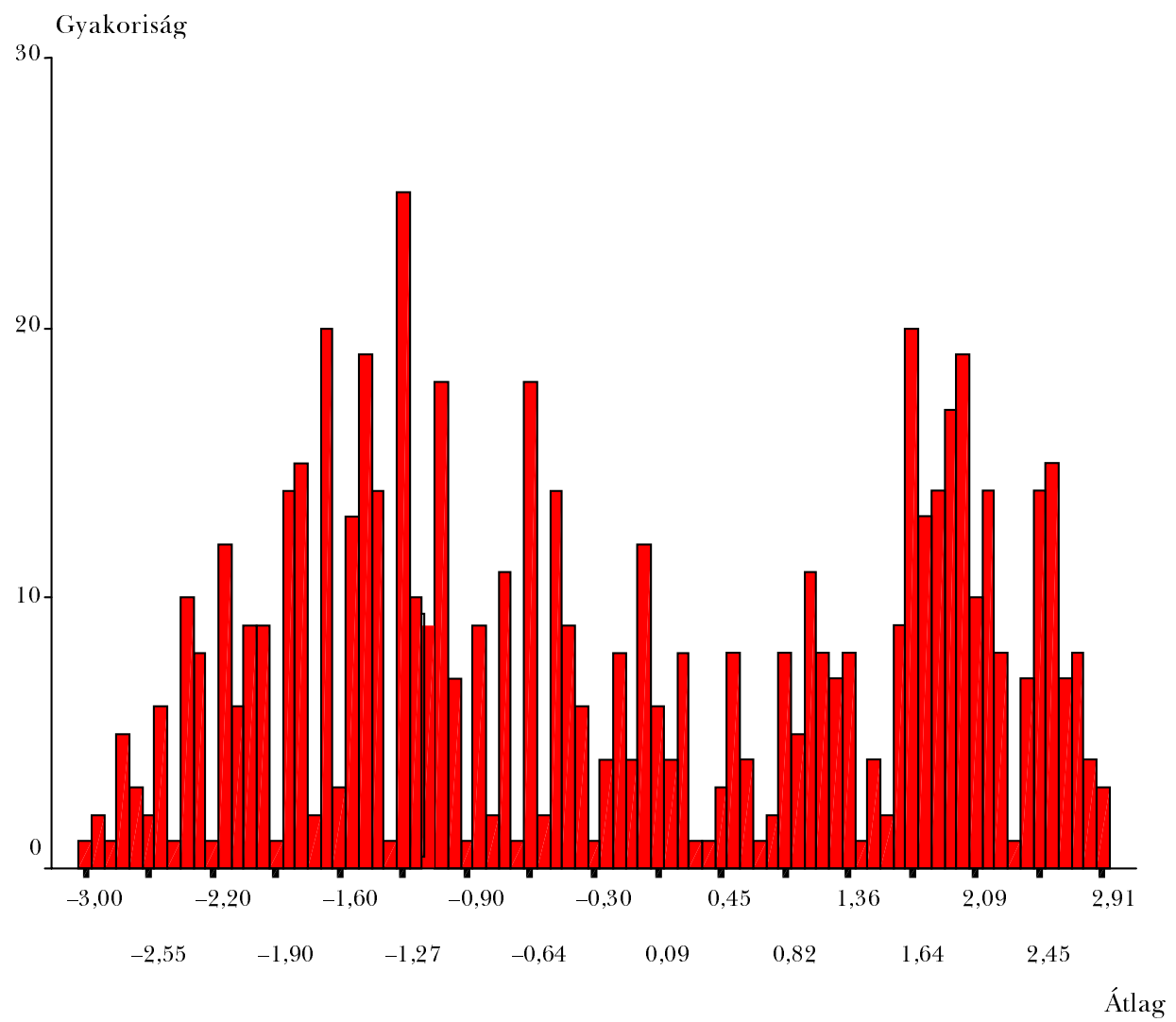

1. ábra. A 620 magyar személyleíró melléknév szociális kívánatosságának gyakoriságmegoszlási grafikonja

\section{IRODALOM}

Allport, G. W., OdBert, H. S. (1936) Trait names: a psycho-lexical study. Psychological Monographs, 47, No. 211.

Anderson, N. H. (1968) Likebleness Ratings of 555 personality-trait words. Journal of Personality and Social Psychology, 9, 272-279.

Angleitner, A., Ostendorf, F., John, O. P. (1990) Towards a taxonomy of personality descriptors in German: A psycho-lexical study. European Journal of Personality, 4, 89-118.

Brokken, F. B. (1978) The Language of personality. Unpublished doctoral dissertation, University of Groningen 
Busz, M., Cohen, R., Poser, U., Schümer, A., Schümer, R., Sonnenfeld, R. (1994) Die soziale Bewertung von 880 Eigenschaftsbegriffen sowie die Analyse der Ähnlichkeitsbeziehungen zwischen einigen dieser Begriffe. In Hager, J., Hasselhorn, M. (eds) Handbuch deutschsprachiger Wortnormen. Hogrefe Verlag für Psychologie, Göttingen, 285-292.

Cowen E. L. (1961) The social desirability of trait descriptive terms: Preliminary norms and sex differences. Journal of Social Psychology, 53, 225-233.

Cowen E. L., Frankel, G. (1964) The social desirability of trait descriptive terms: Applications to a French sample. Journal of Social Pychology, 63, 233-239.

Crowne, D. P. (1979) The Experimental Study of Personality, Erlbaum, Hillsdale

Crowne, D. P., Marlowe, D. (1960) A new scale of social desirability independent of psychopathology. Journal of Consulting Psychology, 24-4, 349-354.

De RaAd, B., Perugini, M., Szirmák, Z. (1997) In pursuit of a cross-lingual reference structure of personality traits: comparisons among five languages. European Journal of Personality, 3, 167-186.

Edwards, A. L. (1957) The Social Desirability Variable in Personality Assesment and Research. Dryden, New York

GOLDBERG, L. R. (1981) Language and individaul differences: the search for universals in personality lexicons. In Wheeler, L. (ed.) Review of personality and social psychology, Vol. 2. Sage, Beverly Hills, 141-165.

GOldberG, L. R. (1982) From Ace to Zombie: Some explorations in the languageof personality. In Spielberger, C. D., Butcher, J. N. (eds), Advances in Personality Assessment, Vol. 1, Erlbaum, Hillsdale, 203-234.

Hampson, S. E., GoldberG, L. R., John, O. P. (1987) Category-breadth and socialdesirability values for 573 personality terms. European Journal of Personality, 1, 241-258.

Hermans, D., De Houwer, J. (1994) Affective and subjective familiarity ratings ff 740 Dutch words. Psychologica Belgica, 34-2/3, 115-139.

IWAWAKI, S., COWEN, E. L. (1964a) The social desirability of trait-descriptive terms applications to a Japanese sample. The Journal of Social Psychology, 63, 199-205.

IwAWAKi, S., COWEN, E. L. (1964b) The social desirability of trait-descriptive terms: further applications to a Japanese sample under a personal set. The Journal of Social Psychology, 63, 207-214.

John, O. P. (1990) The „Big-Five” factor taxonomy: dimensions of personality in the natural language and in questionnaires. In Pervin, L. A. (ed.) Handbook of Personality, Theory and Research. The Guilford Press, New York, 66-100.

Juhász I., SzŐKe I., NAGy G., Kovalszki M. (szerk.) (1972) Magyar értelmezó kéziszótár. Akadémiai Kiadó, Budapest

KLAPPROT, J. (1994) Erwünschtheit und Bedeutung von 338 alltagspsychologischen Eigenschaftsbegriffen. In Hager, J., Hasselhorn, M. (eds) Handbuch deutschsprachiger Wortnormen. Hogrefe Verlag für Psychologie, Göttingen, 293-309.

Klett, C. J., Yaukey, D. W. (1959) A cross-cultural comparison of judgements of social desirability. The Journal of Social Psychology, 49, 19-26.

LÖWAAS, O. I. (1958) Social desirability ratings of personality variables by Norwegian and American college students. Journal of Abnormal and Social Psychology, 57, 124-125.

MAGAY T., OrSZÁGH, L. (szerk.) (1991) Magyar-angol kéziszótár. Akadémiai Kiadó, Budapest

Marlowe, D., Crowne, D. P. (1961) Social desirability and response to perceived situational demands. Journal of Consulting Psychology, 25-2, 109-115. 
Mecklenbräuker, S., Hager, W., Möller, H. (1994) Erwünschtheit von 908 Eigenschaften bei Frauen und bei Männern aus der Sicht von Männern und von Frauen. In Hager, J., Hasselhorn, M. (eds) Handbuch deutschsprachiger Wortnormen. Hogrefe Verlag für Psychologie, Göttingen, 310-328.

Mervielde, I. (1977) Ratings for likableness and subjective frequency of personality traits and interpesonal behaviors. Psychologica Belgica, XVII-2, 143-156.

Millham, J., Jacobson, L. L. (1978/1983) Tetszésigény. In Szakács F. (szerk.), Személyiséglélektani szöveggyüjtemény. IV/2. Személyiségdimenziók mérése. Tankönyvkiadó, Budapest, 363-390.

NORMAN, W. T. (1967) 2800 personality trait descriptors: Normative operating characteristics for a university population. Department of Psychology, University of Michigan

OsGOOD, C. E. (1962) Studies on the generality of affective menaing systems. American Psychologist, 17, 10-28.

Osgood, C. E., Suci, G. J., Tannenbaum, P. H. (1957) The measurement of meaning. Urbana, University of Illinois Press

OstendORF, F. (1990) Sprache und Persönlichkeitsstruktur: zur Validität des Fünf-FaktorenModells der Persönlichkeit. S. Roderer Verlag, Regensburg

Ostendorf, F. (1994) Zur Taxonomie deutscher Dispositionsbegriffe. In Hager, J. and Hasselhorn, M. (eds) Handbuch deutschsprachiger Wortnormen. Hogrefe Verlag für Psychologie, Göttingen, 382-441.

Peabody, D. (1967) Trait inferences: Evaluative and descriptive aspects. Journal of Personality and Social Psychology Monograph, 7, (4 teljes 644. szám)

SCHÖNBACH, P. (1972) Likabliness ratings of 100 German personality-trait words corresponding to a subset of Anderson's 555 trait words. Journal of Social Psychology, 2 (3), 327-334.

SzIrmák, Zs., DE RAAD, B. (1994) Személyiségtaxonómia: A magyar nyelv személyleíró szókincse. Magyar Pszichológiai Szemle, 1-2, 39-65.

Verkasalo, M., Lindeman, M. (1994) Personal ideals and socially desirable responding. European Journal of Personality, 8, 385-393.

\title{
THE SOCIAL DESIRABILITY OF HUNGARIAN PERSONALITY DESCRIPTIVE ADJECTIVES
}

\author{
SZIRMÁK, ZSÓFIA
}

In the study the social desirability is investigated of 620 personality descriptive adjectives from Hungarian personality taxonomy (SZIRMÁK, DE RAAD, 1994). Ten judges rated the social desirability of the personality relevant descriptors on a seven point scale. The average scores, standard deviations, Z-scores and the frequency distribution of the social desirability of the personality relevant adjectives are presented in detail. The study provides a short overview of the previous social desirability studies with special focus on the taxonomy oriented English, Dutch and German social desirability research.

Key words: $\quad$ Personality descriptors, social desirability, personality taxonomy, Big-Five 